\title{
EFFECT OF INNOVATION ON THE EU MEMBER-COUNTRIES ECONOMIC DEVELOPMENT
}

\author{
Julija Bistrova ${ }^{1}$, Natalja Lace ${ }^{2}$ \\ Faculty of Engineering Economics and Management, Riga Technical University, \\ 6 Kalnciema Str., Riga, LV-1048, Latvia \\ E-mails: '1julija.bistrova@rtu.lv; ${ }^{2}$ atalja.lace@rtu.lv (corresponding author)
}

\begin{abstract}
Neoclassical economic theory states that the growth of the nation primarily is dependent on the innovation potential of the country. However, this theory is often being refuted by the recent empirical research, proving that the innovations are becoming more cost-extensive, late in generating return on invested capital and not as useful as they used to be. The present study researches the effect of innovation on the EU member-countries economic development, having selected R\&D expenses, number of patents and number of researchers as innovation proxies. The results prove that there is a strong relationship between the R\&D expenses and GDP growth as well as the labour productivity, but no evidence was found that the number of scientists or the number of patents significantly influence economic development of the country. The authors also ran a regression between the scientific productivity and impact and the GDP per capita to discover the strong relationship between the variables. However, the causality of the relationship should be studied further.
\end{abstract}

Keywords: R\&D expenses, number of patents, innovations, economic development, citations, h-index.

JEL Classification: O32; O34; O47; O52.

\section{Introduction}

The postulates of the neoclassical growth theory that the innovations are one of the major economic growth drivers is well-known in the modern environment, but lately this theory was questioned by a number of researchers (Gordon 2012a, 2012b; Ulku 2004).

Cobb-Douglas function clearly shows that the total output growth is directly influenced by the labour and capital inputs as well as the total factor productivity (TFP), which can be increased by the changes in technology spurred by innovations, changes in laws, in trade restrictions, and in restrictions on capital flows, etc. Coe et al. (2008) empirically prove that $R \& D$ capital stocks have clear impact on the TFP.

The inventions of the previous two centuries undoubtedly were the main reason for the increased standards of living, for economic development at the breath-taking speed. Currently the innovations are the major determinants of the country's competitiveness on the global markets. Ahlstrom (2010) argued in his paper that the main goal of business is the developing innovative products and services to deliver growth.

However, the law of diminishing productivity curve hints that the slowing global growth might indicate that the innovations though still large in their number cannot substantially influence economic development; they often do not add real value, may generate negative return on invested capital (Wessel 2012; Accenture 2013) and often are not accepted on the market (Heidenreich, Spieth 2015; Fischer 2014). The diminishing effect on the output of R\&D departments is well-seen in pharmaceuticals industry - the companies tend to spend more time and money resources relative to the output than they used to.

Therefore, the ultimate goal of this study is to prove or refute the following hypothesis:

Innovations, as proxied by the $R \& D$ expenses in $\%$ of GDP, number of patents and number of researchers, have a value enhancing effect on the total countries' output.

The authors conducted the cross-country study to determine the differences of the population welfare and the innovation potential between the countries to understand whether R\&D investments, number of patents and scientists can be considered to be a 'secret sauce' for the economic development of the nation.

As mentioned before, the authors selected independent variables - R\&D expenses (RD) in \% of 
GDP, number of patents and number of researchers. RD is the innovations input - the potential cost of the inventions but its main shortcoming is the unknown time lag, when the investments innovations will be reflected in GDP growth. Similar to $\mathrm{RD}$ measure is the number of scientists, which is also an 'investment' in future innovations. The patents, however, are the innovations output, representing the successful outcome of the investment, which are supposed to be monetized. Though all these measures are primarily attributed to the industries, these are readily-available data, providing plausible results.

Additionally, the authors considered the scientific potential of the nation by studying the publication impact on the world arena. Scientific inputs studied in the present research were citations per document, citations per capita and h-index, which represents scientific productivity and citation impact of the researchers in the particular countries. These ratios were considered against the GDP per capita ratio. However, again as in case of the above-mentioned ratios one faces the endogeneity problem - whether the increasing quality of scientific publications succeeds further nations' development or whether the 'rich' countries can afford to sponsor thorough researches and are able to attract talents for them to contribute to the number and quality of the good research, the results of which provides well-established basis for nation's further development and increasing quality of life.

\section{Literature review}

Famous economists, authors of the neoclassical economic growth theory, such as Schumpeter (1934), Solow (1956), Romer (1986, 1990), Grossman and Helpman (1994), Jones (1995) state in their works that the innovations is the main power engine of the economic development. Modern scientists conducting empirical research have splitted into two opposing groups - the ones, who provide the evidence to support economic theory, while another group of researchers, which refutes the theory, saying that innovations are not efficient any more and hardly add value but rather require large investments. For example, The Economist (2013) mentions the growing number of researchers and the increasing R\&D expenses in \% of GDP, but also quotes Pierre Azoulay of MIT and Benjamin Jones, who say that the researchers are less efficient - "in 1950 an average R\&D worker in America contributed almost seven times more to "total factor productivity" essentially, the contri- bution of technology and innovation to growth that an R\&D worker in 2000 did".

Gordon in his recent NBER publication (2012a) expresses concern about the innovations development, their usefulness and influence on the economic growth, saying that there are six headwinds that will drag their growth effect down: demography, education, inequality, globalization, energy/environment, and the overhang of consumer and government debt. He is also skeptical about the innovation power to drive the future economic growth in his Wall Street Journal article (Gordon 2012b).

Changtao Wang (2013) taking patents and trademarks registrations as innovation proxies claims than innovatios might not have a significant influence on the economic growth. He states that the role of innovation vaires across the time periods, being very high before World War II and diminshing after it, especially in the major world's innovating nations such as Germany, US and UK.

Leo Sveikauskas (2007) focusing on the R\&D efforts in US clearly distinguishes between the private and public $\mathrm{R} \& \mathrm{D}$, providing the evidence that privately financed $R \& D$ returns are $25 \%$, while state financed $R \& D$ returns are near zero.

Patent rights achieve their main aim to increase standard of living and therefore, support economic growth - evidence proof is provided by $\mathrm{Hu}$ and Png (2013), who researched 54 manufacturing industries in 72 countries. They have concluded that growth in the patents-intensive industries is to a large extent dependent on the patent rights. Patents have also greater effect in higher-income countries. Supporting this evidence, Westmore (2013) discovered significant relationship between the innovation indicators (R\&D expense and number of new patents) and multifactor productivity growth (MFP) across 19 OECD countries. 20 OECD and 10 non-OECD countries were researched by Hulya Ulku (2004) to investigate implications of $R \& D$ growth models. It was concluded that innovations do not always lead to economic growth. However, theauhor does not suggest to cease investments in innovations, as $R \& D$ and patents do not capture full scope of innovations

Macro-level analysis of Japanese and S. Korean cases was made by the Sinha (2008), when he concluded that GDP exerts influence on the number of patents, while he was not able to determine the reverse causality.

Another Asian economy, Taiwanese, was researched by Chih-Hai Yang (2006), who proved in his publication that the increase in patenting 
positively influences economic growth, while the long-term growth is largely driven by the worldwide discoveries.

Kokko et al. (2015) in their research on EU15 countries state that though there is similar effect of $\mathrm{R} \& \mathrm{D}$ on economic growth, the effect is less prominent compared to USA. The difference in the article was explained by the higher private investments and higher linkages between public and private investments.

Concluding the literature review section the authors need to metion Capolupo's review (2009), who stated that the endogenuous growth models, which include also innovation factors, increase their predictive power and empirical support.

\section{Research design}

The first step in the project is dedicated to the discovery of the innovation value-added effect to the economy development on macro- and microlevel, therefore the present paper provides an overview of the European Union member-countries' innovation potential determinants' current status and their historical perspective. The key data the authors consider are RD investments in \% of GDP, number of patents and number of researchers.

Two periods were analyzed: $1.1996-2013$ to have a complete historical overview; 2. 2003-2013 to have a more recent overview, which might be more relevant to the current situation.

A number of regression equations were used to achieve the study goal of discovering how the innovation potential determinants influence GDP growth, stock market performance and the productivity of the economy, which is described hereas labour productivity and total factor productivity:

$$
\begin{aligned}
G D P \%= & \propto_{0}+\propto_{1} * R D \%+\propto_{2} * \text { Patents } \%+ \\
& \propto_{3} * \text { Researchers } \%,
\end{aligned}
$$

where:

GDP \% GDP Compound annual growth rate (CAGR);

$R D \% \mathrm{R} \& \mathrm{D}$ expenses CAGR;

Patents \% Number of patents CAGR;

Researchers \% Number of researchers CAGR (only considered for a shorter period of 2003-2013 as earlier data was unavailable).

The authors accout for one year lag for the dependent variable versus the independent variables to allow a certain time as the effect of the investments turning into the monetary benefit is not immediate.
The following list presents other indicators, which were used as ' $y$ ' in the regressions for the same ' $x$ ' mentioned above:

- Labour productivity \% - Labour productivity (Euro per $\mathrm{H}$ worked) compound annual growth rate;

- TFP \% - Total factor productivity estimated as Tornqvist index CAGR;

- Stock Index \% - Country stock index performance CAGR (only considered for shorter period of 2003-2013 as earlier data was unavailable for all countries).

TFP was selected for the testing as according to the economic theory, this indicator should be directly influenced by the innovations. The stock market value was added to the selection of the dependent variables as it tends to be the leading indicator of the nation's development and economic growth.

Additionally, the authors considered the regression, where per capita data were used for the most recent year under review:

$$
\begin{aligned}
\text { GDP per cap. }= & \propto_{0}+\propto_{1} * \frac{\text { Population }}{\text { Number ofscientists }}+ \\
& \propto_{2} * \frac{\text { Population }}{\text { Number of patents }} .
\end{aligned}
$$

This equation was used to understand whether the welfare of a person, as described by GDP per capita, is to a certain extent dependend on the number of scientists or the registered patents relative the population of the country.

Three primary sources of information were used in the process of research: WorldBank, Eurostat and the Conference Board Total Economy Database.

SCImago Journal and Country Rank portal, which provides scientific indicators based on Scopus database, was the primary datasource for the authors to obtain such indicators as scientific productivity, number of citations and publications etc. As Kurzemniece and Bažbauers (2014) indicate Scopus database tends to be the largest scientific database, which is the best indescribing world's scientific structure and includes also Thomson Reuters Web of Science journals. The combined indicators for countries used in the present research were as follows:

- Number of citations, to see its dynamics and to derive number of citations per capita;

- Citations per documents to see how significant is the general scientific impact of a nation; 
- H-index, which provides an overview of the impact and quality of the research output and is based on the number of citations and number of publications combination.

The relationship of GDP per capita with the mentioned scienitifc indicator were tested with the help of regression.

\section{Research results}

\subsection{Current and historical view on state innovation potential}

R\&D investments as defined by UNESCO Institute of Statistics are directed to "creative work undertaken systematically to increase knowledge, including knowledge of humanity, culture, and society, and the use of knowledge for new applications", which means the investment in the development of the nation. It also means that these investments are expected to provide monetary benefits in the future. Figure 1 chart provides a cross-country comparison of the $R \& D$ expenses relative to the country's GDP. Top 3 positions are taken by the Northern European countries - Finland, Denmark and Sweden (if Norway is included with $1.65 \%$, it would be in the middle of the sample).

The lowest amount dedicated to $R \& D$ is seen in the developing economies (which still have lowest GDP per capita among EU members) such as Romania, Bulgaria, and Latvia. Greece, obviously struggling with the very poor economic conditions, is investing in $\mathrm{R} \& \mathrm{D}$ similarly low amount of GDP.

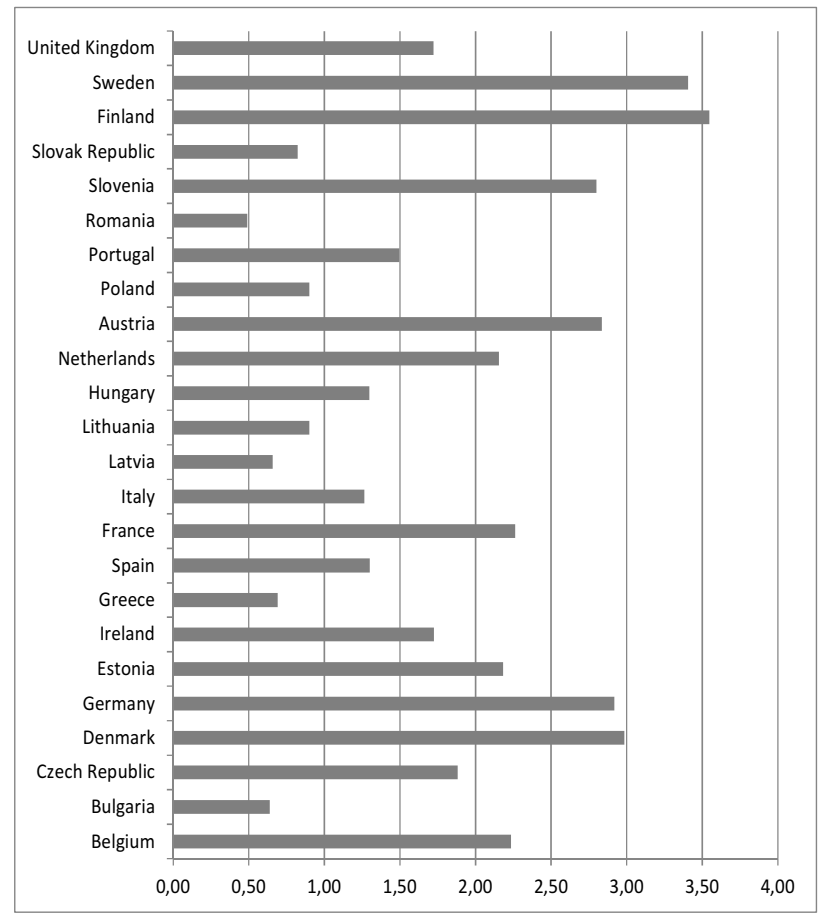

Fig. 1. R\&D Expenses in \% of GDP, 2012 (Source: compiled by the authors according to Worldbank data)

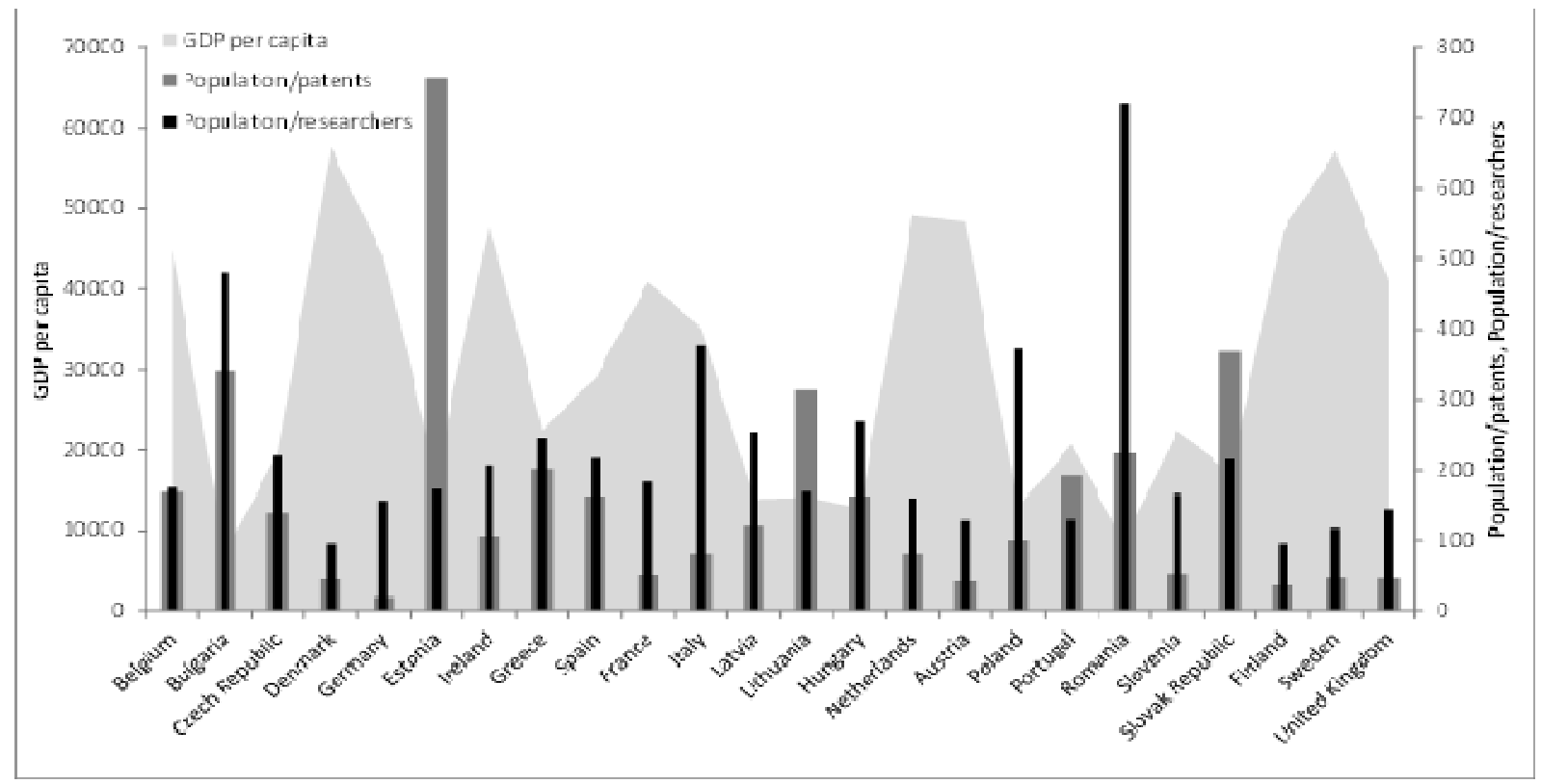

Fig. 2. Number of patents and number of researchers vs. GDP level, 2012

(Source: authors' calculations using Worldbank data) 
Estonia being a developing country is certainly worth mentioning as it obviously pursues a long-term strategy make as significant investments in R\&D as France, Belgium and Netherlands. Substantial increase in R\&D investments in 2011 and 2012 were made in developing Slovenia, taking the country in the top league.

Chart of Figure 2 compares the number of patents and researchers relative to the population, while also providing the view of the population welfare as measured by GDP per capita.

The lowest number of patents relative to the overall country's population is exhibited by the developed nations with the large population. Though developed, Greece, Belgium and Spain are attractively different in terms of the number of patents, which leads to the need of further investigation of the laws regulating patent registration procedure. Patent-rich countries relative to the population size are rather new EU members Estonia, Lithuania and Slovakia.

Analysis by the number of researchers relative to the population provides the possibility to create clusters once again - developed and developing nation, with the latter usually having higher number of researchers having some exceptions naturally. Top four countries in the number of researchers are Romania, Bulgaria, Italy and Poland, followed by Latvia and Hungary.

Taking the number of the patents vs. the number of researcher, one concludes that according to this measure, the most 'productive' nations are the researchers from Estonia, Lithuania and Slovakia. The least productive, however, are developed countries with the extensive research bases Germany and Italy as well as developing Romania.

The positive trend about the whole sample countries is increasing importance of the investments in research, applied research and experimental development (Fig. 3), the growth of which exceed the rate of inflation in majority of the analyzed countries.

Annual growth in the number of scientists is similarly observed in all countries under review, which is a good sign. To add, the policy-makers on the macro and micro-levels have to ensure the efficiency of the research and the system overall.

Unlike growing $R \& D$ and the number of scientists, in several countries both developing and developed patents are in decline - in Ireland, Bulgaria, Hungary, Denmark, UK, Slovakia, Finland, Sweden.

\subsection{Influence of innovations on the economic growth determinants}

Innovation proxies - R\&D expenses, number of patents and scientists - were first tested to eliminate cross-correlation to avoid multicollinearity problem. In both periods the correlation was lower than $50 \%$ with $\mathrm{R} \& \mathrm{D}$ ratio correlating the least with the number of patents and scientists.

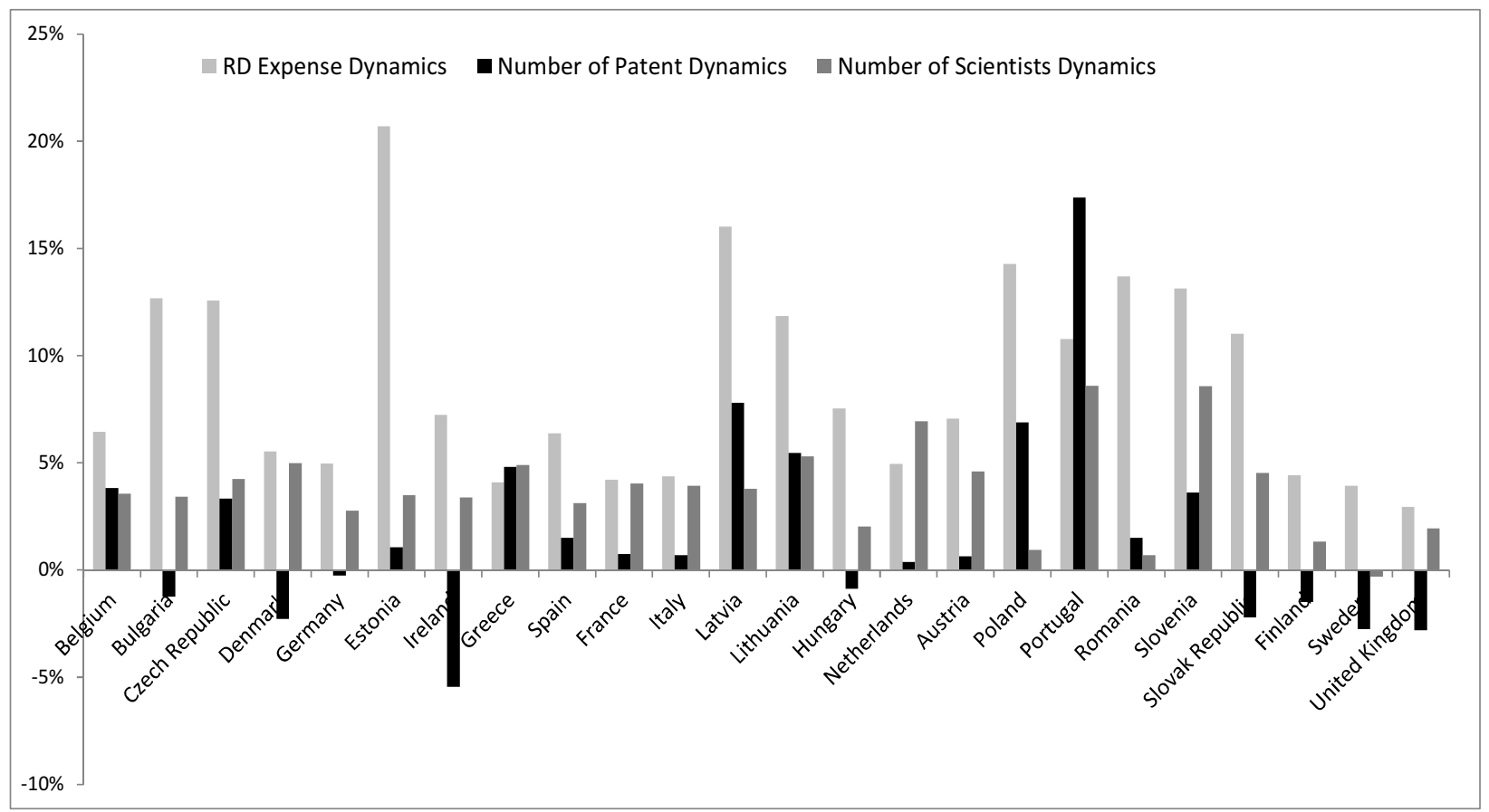

Fig. 3. RD expenses, number of patents and researchers compound annual growth rate, 2003-2012 (Source: authors' calculations using Worldbank data) 
The relationship of independent variables on the GDP growth according to the regression results appears to be the most significant (Table 1) and the relationship importance didn't diminish in the most recent time period as $\mathrm{R} 2$ increased from $75.5 \%$ to $77 \%$ (Table 2). Noteworthy, number of patents growth has a significant inverse relationship. Partially this phenomenon is explained by the decreasing number of patents in the emerging countries such as Bulgaria, Hungary and Romania, which all post very high GDP growth on annual basis.

Table 1. Regressions statistics (1996-2013) (Source: authors' calculations)

\begin{tabular}{l|l|l|l}
\hline & Coefficients & t-stat & p-value \\
\hline Y= GDP\%: R Square $=\mathbf{7 5 . 6 \%}, \mathbf{F}=\mathbf{3 2 . 5 1}$ \\
\hline Constant & 0.018 & 2.715 & 0.013 \\
\hline RD\% & 0.571 & 7.745 & 0.000 \\
\hline Nr. of patents \% & -0.328 & -3.918 & 0.001 \\
\hline $\begin{array}{l}\text { Y labour productivity: R Square }=\mathbf{6 2 . 4 \%} \\
\text { F = 17.43 }\end{array}$ \\
\hline Constant & -0.002 & -0.481 & 0.636 \\
\hline RD\% & 0.321 & 5.793 & 0.000 \\
\hline Nr. of patents \% & -0.151 & -2.402 & 0.026 \\
\hline Y $=$ TFP\%: R Square $=\mathbf{8 . 2 \%}, \mathbf{F}=\mathbf{0 . 9 4}$ \\
\hline Constant & 0.182 & 0.339 & 0.738 \\
\hline RD\% & 4.950 & 0.829 & 0.417 \\
\hline Nr. of patents \% & -8.480 & -1.251 & 0.224 \\
\hline
\end{tabular}

The similar relationship, but exhibiting lower significance, is obtained when labour productivity is tested as the dependent variable. Total factor productivity, according to the Table 1 results, is not dependent on either of the variables.

Shorter more recent time period increases the significance of all the regressions run in the research process - strong relationship with GDP and labour productivity, while again number of patents and number of scientists have inverse relationship, their influence becomes insignificant.

None of the independent variables have a significant relationship to the TFP or the local stock market.

Additional regression, which considered per capita data, was run on the most recent available data (Table 3). F-significance of 0.00095 shows that the number of patents and number of scientists relative to the country's population size have a significant relationship to the GDP per capita, hinting that the higher is the number of patents or scientists, the higher is the welfare of the population.
Table 2. Regressions statistics (2003-2013) (Source: authors' calculations)

\begin{tabular}{l|l|l|l}
\hline & Coefficients & t-stat & p-value \\
\hline Y = GDP: R Square $=\mathbf{7 7 . 0 \%}, \mathbf{F}=\mathbf{2 2 . 3 3}$ \\
\hline Constant & 0.018 & 2.304 & 0.032 \\
\hline RD\% & 0.459 & 7.262 & 0.000 \\
\hline Nr. of patents \% & -0.009 & -0.128 & 0.899 \\
\hline Nr. of scientists \% & -0.426 & -2.993 & 0.007 \\
\hline Y = labour productivity: R Square $=\mathbf{7 2 . 8 \%}$, \\
F= 17.86 & -0.003 & -0.684 & 0.502 \\
\hline Constant & 0.214 & 6.851 & 0.000 \\
\hline RD\% & -0.006 & -0.173 & 0.864 \\
\hline Nr. of patents \% & -0.525 & 0.605 \\
\hline Nr. of scientists \% & -0.037 & -1.584 & 0.129 \\
\hline Y $=$ TFP \%: R Square $=\mathbf{2 1 . 3 \% , ~ F ~ = ~ 1 . 8 0 4 ~}$ \\
\hline Constant & -0.008 & 2.247 & 0.036 \\
\hline RD\% & 0.097 & -0.401 & 0.693 \\
\hline Nr. of patents \% & -0.020 & -0.377 & 0.710 \\
\hline Nr. of scientists \% & -0.036 & 1.080 & 0.293 \\
\hline Y=stock index\%: R Square $=\mathbf{2 2 . 4 \% , ~ F ~ = 1 . 9 3 ~}$ \\
\hline Constant & 0.026 & 1.162 & 0.259 \\
\hline RD\% & 0.223 & -0.585 & 0.565 \\
\hline Nr. of patents \% & -0.128 & -1.677 & 0.109 \\
\hline Nr. of scientists \% & -0.726 & \\
\hline
\end{tabular}

Table 3. Regressions statistics (2013) (Source: Analysis by per capita data)

\begin{tabular}{c|c|c} 
Coefficients & t-stat & p-value \\
\hline
\end{tabular} $\mathrm{Y}=$ GDP per capita: $\mathbf{R}$ Square $=\mathbf{4 6 . 9 \%}, \mathbf{F}=\mathbf{9 . 7 1}$

\begin{tabular}{l|l|l|l}
\hline Constant & 57837.89 & 8.801 & 0.000 \\
\hline Population/researchers & -72.07 & -2.970 & 0.007 \\
\hline Population/patents & -0.62 & -2.541 & 0.019 \\
\hline
\end{tabular}

However, one might question the endogeneity of the economic indicators - whether it is the innovation power that led to the GDP being on the high level or whether the country having GDP per capita on a decent level can afford excellent scientific base.

\subsection{Scientific impact and population welfare}

Citations per capita visual representation by EU countries allows again to divide the research sample in two groups: developed with higher citation rate per capital and emerging markets with lower number of citations per capita. Again the exception here is Estonia, which obviously is heading towards the developed countries' elite (Fig. 4). 


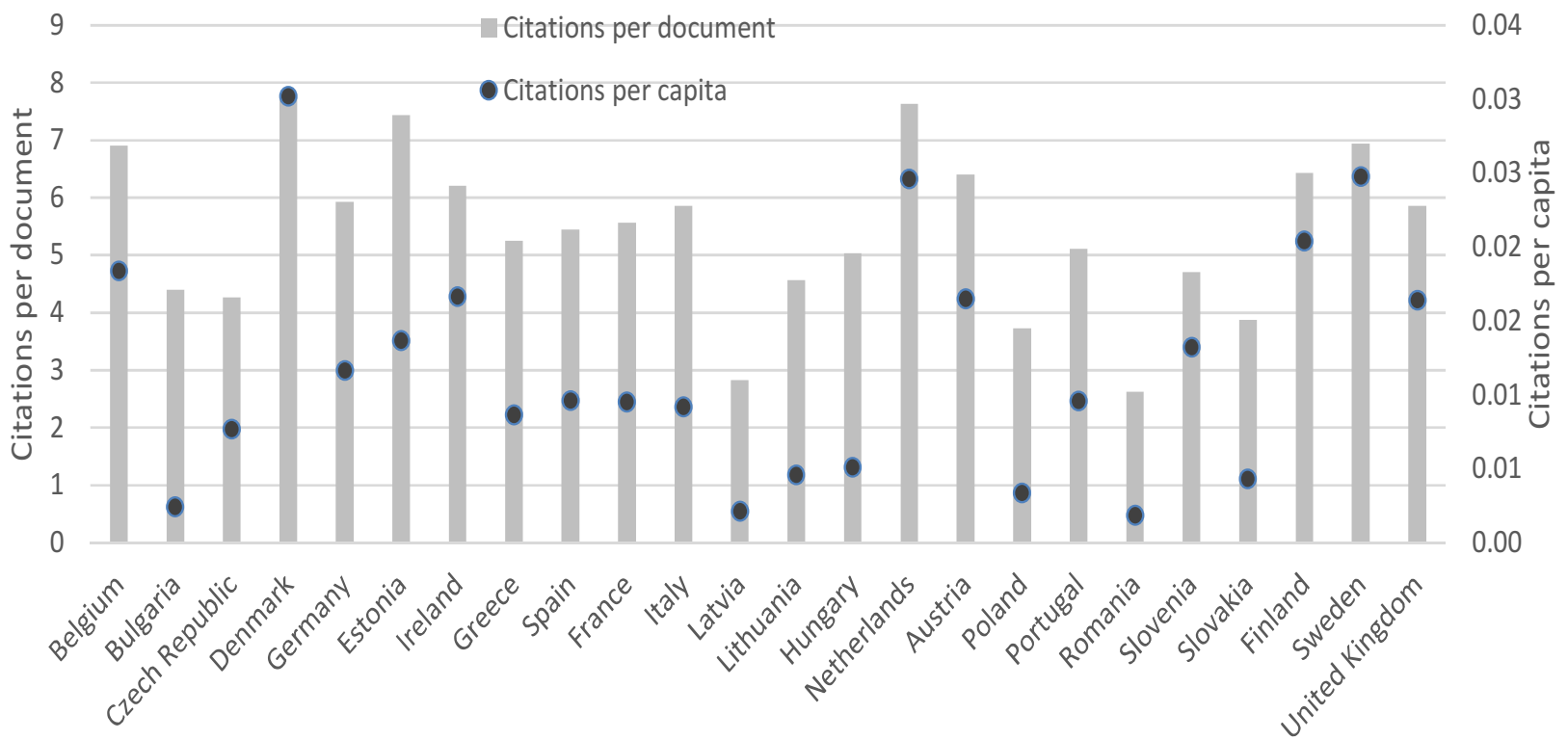

Fig. 4. Average citations per document and number of citations per capita of EU countries (2012)

(Source: authors' calculations according to the SCImago Journal)

Finland, Denmark, Sweden and Netherlands can be distinguished by the very high citations per capita ratios.

The most impactful publications among the European Union members are being produced in Estonia, Denmark, Belgium and Sweden.

Regression results in the Table 4 provide a very strong evidence that there is a significant relationship between the GDP per capita and citations per capita as well as scientific impact and productivity as depicted by the h-index.

Table 4. Regressions statistics (2013) - GDP per capita and Country's Scientific Impact (Source: authors' calculations)

\begin{tabular}{l|l|l} 
Coefficients & t-stat & p-value \\
\hline
\end{tabular}

$\mathrm{Y}=$ GDP per capita: $\mathbf{R}$ Square $=\mathbf{8 7 . 9 \%}, \mathbf{F}=\mathbf{7 6 . 5 2}$

\begin{tabular}{l|c|c|c}
\hline Constant & 3545 & 1.31 & 0.204 \\
\hline Citations per capita & 1588908 & 8.43 & 0.000 \\
\hline h-index & 22 & 3.84 & 0.001 \\
\hline
\end{tabular}

The obtained results indicate that the more is the scientific productivity and impact in the academic world, the higher is the country's GDP per capita.

\section{Conclusions}

The results obtained through the graphical analysis allowed to make the conclusion that there is a very positive trend in increasing $R \& D$ expenses, which points to the understanding of the society that innovations have a significant role in generating future benefits and the need to invest in long-term. The number of scientists is growing in all sample countries, but the number of patents in several states show a declining trend, which possibly demonstrates the diminishing productivity effect, but the statement need a further proof.

Intensity of $R \& D$ investments clustered the sample into the developing and developed nations, demonstrating that the latter on average invest more in $R \& D$ on relative basis. In opposite, the developing countries often have a higher share of researchers in total population than do the developed countries.

The primary goal of the research to test the hypothesis whether innovations add value to the economic development was achieved when running regression for longer period and more recent period of the last 10 years. Regressing $R \& D$ expenses on the GDP growth and labour productivity in time periods appeared to be significant. Number of patents' dynamics and number of researchers' dynamics did not show any significant relationship to the GDP growth (exc. in longer time period regression number of patents growth showed negative relationship to GDP development).

Selected as dependent variables, stock market growth and total factor productivity, were not proved as being depended on any of the innovation proxies.

Additional regression run by the authors considered the indicators relative to the population 
size. Both variables, population/researchers and population/patents have negative relationship to the welfare of the nation.

Based on the above stated, the hypothesis of innovations value-adding effect was proved, but not on all of the independent variables' dimensions.

When testing the influence of scientific potential of the nation on the country's GDP per capita, there was a strong relationship found. The productivity of scientists and the quality of their publications, which was indicated by the citations' frequency, have high impact on the population's welfare. Therefore, the study results provide a good reason to the discussion on funding scientific research by the government and private institutions. However, one should also consider the endogeneity of the problem to understand the true causality of the relationship.

\section{Acknowledgements}

The paper was supported by the project „The Development of Innovation and Entrepreneurship in Latvia in Compliance with the Smart Specialization Strategy" within the National Research Program 5.2. "Economic Transformation, Smart Growth, Governance and Legal Framework for the State and Society for Sustainable Development - a New Approach to the Creation of a Sustainable Learning Community (EKOSOC-LV)".

\section{References}

Accenture. 2013. Accenture study: innovation efforts falling short despite increased investment [online], [cited 15 February 2016]. Available from Internet: https://newsroom.accenture.com/subjects/supplychain-management/accenture-study-innovationefforts-falling-short-despite-increasedinvestment.htm

Ahlstrom, D. 2010. Innovation and growth: How business contributes to society, The Academy of Management Perspectives 24(3): 11-24. http://dx.doi.org/10.5465/AMP.2010.52842948

Capolupo, R. 2009. The new growth theories and their empirics after twenty years, Economics: The Open-Access, Open-Assessment E-Journal 3(1): 172. Coe, D. T.; Helpman, E.; Hoffmaister, A. W. 2008. International $R \& D$ Spillovers and Institutions, IMF Working Paper, WP/08/104.

The Economist. 2013. Has the ideas machine broken down? [online], [cited 15 January 2016]. The Economist, January 12, 2013. Available from Internet: http://www.economist.com/news/briefing/2156938 1-idea-innovation-and-new-technology-havestopped-driving-growth-getting-increasing
Fischer, A. 2014. Why most innovations are great big failures [online], [cited 15 February 2016]. Available from Internet:

http://fortune.com/2014/10/07/innovation-failure/

Gordon, R. J. 2012a. Is US economic growth over? Faltering innovation confronts the six headwinds. NBER Working Paper No. 18315.

Gordon, R. J. 2012b. Why innovation won't save us, [online], [cited 15 January 2016]. Available from Internet:

http://www.wsj.com/articles/SB100014241278873 24461604578191781756437940

Grossman, G. M.; Helpman, E. 1994. Endogenous innovation in the theory of growth, Journal of Economic Perspectives 8: 23-44.

Jones, Ch. I. 1995. R\&D-based models of economic growth, Journal of Political Economy 103: 759784. Heidenreich, S.; Spieth, P. 2013. Why innovations fail-The case of passive and active innovation resistance, International Journal of Innovation Management: 17(05): 1350021.

Hu, A. G. Z.; Png, I. P. L. 2013. Patent rights and economic growth: Evidence from cross-country panels of manufacturing industries, Oxford Economic Papers 65( 3): 675-698.

Kokko, A.; Tingvall, P. G.; Videnord, J. 2015. The growth effects of R\&D spending in the EU: A meta-analysis, Economics 9(40): 1-26.

Kurzemniece, I.; Bažbauers, G. 2014. Zinātniskās darbūbas rezultātu izvērtējums specializāciju noteikšanai pētniecībā. Rīga: LU akadēmiskais apgāds.

Romer, P. 1986. Increase returns and long run growth. Journal of Political Economy 94(5): 1002-1037. http://dx.doi.org/10.1086/261420

Romer, P. M. 1990. Endogenous technological change, Journal of Political Economy 98(5): 71-102. http://dx.doi.org/10.1086/261725

Scimago Journal. Available from Internet: http://www.scimagojr.com/

Schumpeter, J. A. 1934. The theory of economic development: An inquiry into profits, capital, credit, interest, and the business cycle. Vol. 55. Transaction publishers.

Sinha, D. 2008. Patents, innovations and economic growth in Japan and South Korea: evidence from individual country and panel data, Applied Econometrics and International Development 8(1): 181-188.

Solow, R. M. 1956. A contribution to the theory of economic growth, The Quarterly Journal of Economics 70(1): 65-94. http://dx.doi.org/10.2307/1884513

Sveikauskas, L. 2007. $R \& D$ and productivity growth: $a$ review of the literature. U.S. Bureau of Labor Statistics Working Paper No. 408.

Ulku, H. 2004. R\&D, Innovation, and economic growth; an empirical analysis. IMF Working Papers 04/185. International Monetary Fund. 
Wang, Ch. 2013. The Long-run Effect of Innovations on Economic Growth. Paper Prepared for the IARIWUNSW Conference [online], [cited 15 February 2016]. Available from Internet:

http:/www.iariw.org/papers/2013/WangPaper.pdf

Wessel, M. 2012. Why big companies can't innovate [online], [cited 15 February 2016]. Available from Internet:

https://hbr.org/2012/09/why-big-companies-cantinnovate
Westmore, B. 2013. R\&D, patenting and growth: the role of public policy. OECD Economics Department Working Papers No. 1047. OECD Publishing, Paris.

http://dx.doi.org/10.1787/5k46h2rfb4f3-en

Yang, C. H. 2006. Is innovation the story of Taiwan's economic growth?, Journal of Asian Economics 17(5): 867-878. 